\title{
Offshoring Decisions: A Comprehensive \& Conceptual Framework
}

\author{
Amulya Gurtu \\ Austin E. Cofrin School of Business \\ University of Wisconsin-Green Bay, WI, USA \\ E-mail: gurtua@uwgb.edu (Corresponding Author) \\ Ramesh Saxena \\ The Business School \\ Humber College, Toronto, ON, Canada \\ E-mail: ramesh.saxena@humber.ca \\ Nilesh B. Sah \\ Department of Finance \& Economics, Gary W. Rollins College of Business \\ University of Tennessee at Chattanooga, USA \\ Email: nilesh-sah@utc.edu
}

\begin{abstract}
The paper presents complexities involved in offshoring decisions and provides a comprehensive framework for making a reliable decision for offshoring. There is a need for a holistic approach to offshoring decisions. The paper identifies various drivers, categorizes them as revenue or cost drivers, and analyzes their impact on the offshoring outcomes. The framework rationalizes the extremes of unprecedented successes and unexpected failures among organizations engaged in offshore outsourcing. The proposed framework is expected to improve the quality of offshoring decisions. The proposed framework approaches offshore outsourcing decisions at a strategic level and will improve organizations' performance on the triple bottom line.
\end{abstract}

Keywords: offshoring, outsourcing, globalization, corporate and social responsibility, sustainability.

\section{INTRODUCTION}

A strategic business decision is governed by the principles of cost-benefit analysis, and outsourcing decisions are no exceptions. The literature on the offshoring revolves around the factors related to the cost savings, while the literature on the effects of the offshoring on increasing revenue (sales) is almost nonexistent. This paper presents a framework for identifying drivers of offshore outsourcing, explores the main drivers of cost and benefit, and evaluates the impact of these drivers on an organization. The use of the terms outsourcing, offshoring, and offshore outsourcing has been on the rise for a long time. However, these terms are often used interchangeably. While "offshore outsourcing" and offshoring mean the same, outsourcing has a different definition. Offshore outsourcing or offshoring describes "a business's (or a government's) decision to replace domestically supplied service functions with imported services produced offshore" (OECD, 2016). The term outsourcing is defined as "delegating (part of) activities to an outside contractor"
(OECD, 2016) within a nation.

Outsourcing causes a shift in the location of economic activities within a nation. Emissions and employment largely remain unaffected within a nation. Therefore, outsourcing has a negligible environmental or social impact in a nation. The employment affects many social factors, such as retail economic activities, community development, indirect employment, crime, poverty levels, the costs of healthcare, the collection of federal, state, and municipal taxes. But, the effects of offshoring have global environmental and societal effects (Gurtu, et al., 2016b). There is extant academic literature on offshore outsourcing, and an overwhelming majority of the literature is dedicated to the savings in operational expenses due to the lower cost of labor in outsourced nations. The notion of savings in the labor cost as the main driver behind offshore outsourcing is a fallacy, which is discussed in detail later. Nonetheless, the academic literature on other drivers that influence offshore outsourcing and their effects on decision-making processes is scanty. There is a strong need to fill this gap, and this paper is a step in that direction.

This paper not only presents a framework for identifying drivers of offshore outsourcing but also explores the drivers of both costs and benefits. The paper also evaluates the impact of these drivers on an organization in either reducing costs or improving revenue. Therefore, the purpose of this paper is to (i) provide a critical perspective on the notion of savings in labor cost due to offshore outsourcing, (ii) present an alternate paradigm that the labor cost savings is not the primary driver of offshore outsourcing decisions, (iii) fill this gap by discussing important drivers of costs as well as benefits and, (iv) present an expanded framework to identify drivers of offshoring. The framework presented in this paper will address the issue of decision making that determine whether an organization should engage in offshore outsourcing. 
A business decision has the potential of many outcomes between the two extremes of a grand success and a catastrophic failure (Lahiri, 2016). The most likely reason for an unpredictable outcome of a business decision between these two extremes is a lack of inclusion of relevant parameters in the decision framework. Some organizations have experienced greater success with offshoring than anticipated due to the errors in estimating benefits. On the other hand, some have experienced failures due to the errors in estimating costs. The nature of estimating other costs is complex and has been acknowledged in the literature (Bock, 2008). Many authors have investigated shortcomings in estimating the costs of offshore outsourcing (Larsen et al., 2013; Stringfellow et al., 2008). These studies corroborate our views that there are gaps in identifying the drivers of offshoring and estimating costs and/or benefits accurately. There is a lack of literature that presents a holistic view of the drivers of offshore outsourcing. This gap in literature motivated us to look at the significance of labor cost in offshoring decisions critically. Further, we looked at offshoring in an all-inclusive manner, identify the drivers of the costs as well as the benefits and present a framework to facilitate offshore outsourcing decisions.

Overwhelming literature considered labor cost savings as the primary driver of offshore outsourcing (Bunyaratavej et al., 2008; Ehie, 2001; Eldenburg et al., 2014; Ellram et al., 2008; Maskell et al., 2007; Mason et al., 2002; Pashupatimath \& Ramakrishna, 2015). Many authors have considered location as an important factor in the offshoring decisions of both manufacturing and services (Bunyaratavej et al., 2007; Bunyaratavej et al., 2008; Gooris \& Peeters, 2014; Jensen \& Pedersen, 2010; Kedia \& Mukherjee, 2009; Mudambi \& Venzin, 2010) with an underlying assumption of reductions in costs. The location is an important factor in manufacturing and the factors affecting the choice of a manufacturing location has changed over time (Tate et al., 2014). Similarly, the use of technology plays a vital role in reducing the cost of offshore outsourcing both for manufacturing and service industries. Varadarajan (2009) has discussed the importance of technology in the service industry for saving operating costs. There seems to be a consensus among the stakeholders that the labor cost savings is the prime motivation behind offshore outsourcing.

This paper examines various drivers, in addition to the labor costs of offshore outsourcing from the perspective of costs as well as benefits. It is not only among a very small stream of studies that review the alternative determinants of the offshore outsourcing decisions, but also the first paper that presents a holistic framework to facilitate offshore outsourcing decisions. An unexpected outcome of an offshore outsourcing decision is experienced due to a failure to include the relevant drivers of costs and/or benefits. Therefore, careful consideration of the drivers of the offshoring on both the sides of the profitability equation, i.e., costs and benefits, is not only important but also essential. The offshore outsourcing of services includes a wide range of services from a low-value service, such as a customer care call center to a high-value service, such as engineering research and development (R\&D) center (Rodríguez \& Nieto, 2016). The decisions related to the offshore outsourcing of services are complex and important. However, the primary focus of this paper is offshore manufacturing because manufacturing processes are more complex and have a wider impact on the environment, and societies than the services. Nonetheless, the framework presented is scalable and can be applied to the offshore outsourcing of services by selecting the appropriate drivers. The rest of the paper is organized as follows: Section 2 presents a literature review; Section 3 presents the decision framework for identifying drivers of offshoring; Section 4 analyzes and discusses the framework in greater detail, and Section 5 presents the conclusion.

\section{LITERATURE REVIEW}

This section examines the literature for the belief that labor cost is the primary driver of offshore outsourcing. It has been portrayed that the savings in the labor costs alone outweigh the additional costs of offshore outsourcing and results in the net savings for an organization. This may be true for a small number of cases. We acknowledge that the cost of labor is an important element in the decision-making process for manufacturing industries and there is a reduction in labor costs due to the offshore outsourcing to developing countries. However, the average difference in the labor costs in manufacturing industries between high-income (developed) countries and low-middle-income (developing) countries is 4.5 percent of the total input cost (Barry \& Reddy, 2006). This figure is slightly dated; more recent data is not available. It is, however, fair to assume that the cost advantage of 4.5 percent has shrunk over the years due to a rise in the labor costs in the developing countries.

A part of the savings from lower labor costs is used towards additional logistics expenses, which reduces the net savings. "Logistics costs is substantial and ranks second only to the cost of goods sold" (Dey et al., 2011). Further, logistics cost has been increasing over the years. Reducing logistics cost for the overall reduction in cost has become a focus in supply chain management (Murray, 2017) clearly indicating that low labor cost alone is a less attractive driver for an offshore outsourcing decision (Sheldon \& Li, 2013; Yamauchi, 2016; Yang et al., 2010). Further, the concept of savings in the costs due to offshore outsourcing for corporations is not limited to the labor costs. Therefore, the notion that labor cost saving is the main driver of offshoring decision is a myopic view of the benefits of offshoring.

The concept of savings is much diversified and bigger than the savings in the labor costs alone. As a result of a gradual increase in costs, many corporations have experienced the erosion of savings and decided to bring their operations back to their home countries, which is commonly referred to as reshoring or on-shoring (Lee, 2014). The primary reason for the reshoring is an increase in the total cost of doing business through the route of offshoring ("Why Reshore?," 2016). The increase in the total cost is further compounded by the availability of skilled labor in outsourced locations. A recent decision by a textile manufacturer to move its manufacturing from China to South Carolina (USA) supports this argument and contradicts the common perception that cheap labor cost is the primary driver of offshoring. The textile organization will have net savings by moving manufacturing from China to South Carolina, USA, 
even though the labor costs are higher in South Carolina, USA than that of China. Keer is a textile company headquartered near Shanghai, China. The leadership team of Keer decided to move their manufacturing to the USA, which will generate about 500 jobs locally at a higher labor cost to the organization. Despite the higher labor costs in the USA, the overall cost of operations will be cheaper for Keer in the USA (Davis, 2016). It is possible that other organizations from the textile industry may follow suit as South Carolina was once the hub of the textile industry in the USA. This move will increase job opportunities in textile manufacturing in the USA. According to an estimate, about 338,000 jobs mainly in manufacturing industries have returned to the USA between January 2010 through 2016 ("Reshoring Initiative," 2017). The above example and the statistics on the reshoring do not support the argument that the labor cost is the primary driver of the offshoring. The decisions related to offshoring versus onshoring of goods or services are affected by a multitude of factors; labor cost is one of the factors. This phenomenon of reshoring or nearshoring has been experienced in relation to other nations as well (Panova \& Hilletofth, 2017; White \& Borchers, 2016).

Multiple factors affecting an offshoring decision have been acknowledged in the literature (Tjader et al., 2010). However, many factors have been bundled as cost savings, though their effects go far beyond the notion of the cost savings. As an example, consumers' preference based on the perceived quality is important but is a less discussed topic in offshoring decisions. A survey involving 319 companies, which were involved in offshore outsourcing, found that quality is an important factor in their business decisions. The survey showed, " $40 \%$ of these companies perceived a trend toward reshoring to the U.S. in their industries. The companies involved in this study also place increasing importance on where their customers want them to locate" (Tate et al., 2014).

The advantages of choosing a location for offshoring have been discussed in the literature by many, as stated earlier. As an example, Kshetri (2007) discussed the offshoring in IT industry from the lens of institutional theory and considered various factors such as regulations, social and cultural habits that help in making an offshoring decision. Later, Kshetri \& Dholakia (2009) reviewed the role of professional and trade associations and found that they facilitate the industry in offshoring through collaboration with the government.

Innovation is another factor affected by offshoring (Mihalache et al., 2012). There are contradictory opinions on the effects of offshoring on innovation (Stanko \& Calantone, 2011). The authors found, "case-based research provides evidence that outsourcing innovation activities can lead to faster product development and cost savings; yet, empirical research shows that outsourcing may lead to higher costs and slower new product development." Another study involving 989 Spanish manufacturing firms from 2006 to 2011 found that offshoring is a key to innovation in production and helps the organizations gain access to greater knowledge, skills, and experience (Valle et al., 2015). Lewin et al. (2009) argued that offshoring is necessary due to the shortage of talent and the highly skilled labor in science and engineering in the USA. Along similar lines, Nassif \& Roe (2009) hold the present high school education system in the USA responsible for not providing required skills to the workforce and forcing businesses in the direction of the offshore outsourcing. "This is a novel argument, as the USA has generally not had a shortage of skilled workers and other literature does not indicate that the quality of American high school education is a driver for reversing offshore outsourcing or job losses" (Gurtu et al., 2016b).

The offshoring reduces the labor costs on the one hand, but on the other hand, increases such costs as the overhead and the logistic costs of doing business. However, increases in the costs and advantages other than the labor costs in the offshoring decisions are discussed sparingly in the literature. "Micro and macro level impacts of offshore outsourcing are far from clear. Thus, there are some well-founded rationales for and against offshore outsourcing as well as a number of misinformed and ill guided viewpoints" (Kshetri, 2007). Similar sentiments were echoed later in the literature that the decisions related to outsourcing are marred with inappropriate and incorrect assumptions (Lee, 2014). There are many advantages of offshore outsourcing other than the savings in the total labor cost. It is imperative to examine the other "advantages" of the offshore outsourcing in addition to the savings in labor costs and weigh them against the increases in the logistics, communication, travel and other administrative costs.

An empirical study conducted by (Lahiri, 2016) questions the entire premise of outsourcing as a tool for improving organizations' performance. The author questions whether the net cost savings are enough to improve organizations' performance through offshore outsourcing. The author reviewed 57 empirical studies in 47 peerreviewed journals between 1996 and 2015 and found that the result of outsourcing can produce any result from "positive, negative, mixed, moderate or no impact" on organizations. In other words, outsourcing does not necessarily always lead to a positive outcome, i.e., net savings (Hagerty \& Magnier, 2015). This gap in performance is a direct result of a lack of inclusion of all the relevant drivers of offshoring, as well as, gaps in defining parameters leading to success or positive outcome through offshore outsourcing.

Therefore, offshore outsourcing decisions need to be holistic in nature and aimed at improving firms' performance, rather than focusing on reducing costs. There are some authors, who investigated other potential drivers of offshore outsourcing decisions (Kshetri, 2007; Kshetri \& Dholakia, 2009; Lewin et al., 2009; Valle et al., 2015) which will be discussed later in the paper in detail. As an example, Musteen (2016) has recently examined 22 cases from six diverse industries and corroborated that there are important factors other than the costs that affect the offshoring decision. The author examined them through the behavioral lens. Another study explored the concerns associated with the offshore outsourcing of customer service (Honeycutt et al., 2012). Offshoring bears legitimate concerns around the safety and security of the personal information being sent overseas, with the potential of being misused if fallen into the wrong hands. An additional concern with offshore outsourcing of customer services relates to cultural and communication barriers. The authors suggested developing a strategy to minimize the impact of culture and communication barriers to improve customer satisfaction (Honeycutt et al., 2012). Kedia and Lahiri (2007) have 
looked at the outsourcing of services to various developing countries and classified the engagements into three categories, namely tactical, strategic, and transformational. The authors further presented a model for partnership based on the drivers on both the sides of participants. In adopting this approach, we present a rigorous discussion about some of the important, though less-discussed drivers of offshore outsourcing alongside their pros and cons. Our paper contributes to the literature by presenting a framework for identifying the drivers of offshoring and discussing these less-discussed drivers of the offshoring.

\section{FRAMEWORK}

This section describes a general framework to identify the drivers of offshore outsourcing and their impact on organizations' performance. The drivers of offshore outsourcing are divided into two broad categories (Figure 1) - (i) Revenue Drivers, which directly affect the top line (revenue/sales) of an organization and (ii) Cost Drivers, which directly affect bottom line without affecting the top line of an organization. The drivers which affect top-line revenues will also indirectly affect the bottom line. Bottom line revenues are further divided into two sub-categories - (iiA) cost saving drivers: the drivers that lead to the upfront savings from incurring expenses for doing business and (iiB) cost avoidance drivers: the drivers that lead saving from potential expenses in the future generally in the form of compensations, penalty or litigation costs.

Some of these drivers are well-known, and others are not so well-known. The two drivers, labor and manufacturing costs that are noted under the cost savings category are well documented in the academic literature. The cost advantage in manufacturing industries comes from low labor costs (Keuschnigg \& Ribi, 2009; Marin, 2006; Parida et al., 2016; Pashupatimath \& Ramakrishna, 2015; Rugman \& Verbeke, 2004) and economies of scale (Cachon \& Harker, 2002; Holcomb \& Hitt, 2007). Hence, little focus has been given to these drivers in this paper. The rest of the drivers are less explored and are the focus of this paper. These are discussed in the next sub-sections titled Revenue Drivers and Cost Drivers in detail.

\subsection{Revenue Drivers}

The top block in Figure 1 represents revenue drivers, which are meant to increase revenue. This is divided into three sub-groups of drivers. These sub-groups are access to regional markets for new products, access to secondary markets in a region and access to talent pools in a region. These are discussed in the next three sub-sections.

\subsubsection{Access to Regional Markets}

Offshore outsourcing provides access to new and untapped markets (Ghodeswar \& Vaidyanathan, 2008; Javalgi et al., 2009), which helps in increasing sales revenue. Access to two countries, India and China alone, provides access to about three times the combined population of the European Union (EU) and North America, which is a huge opportunity for offshoring organizations. In addition to an increase in sales revenue through the sale of existing unused products, a non-mature market is a laboratory for experimenting with various new products, new services, and new policies without affecting the established customer bases in the mature markets. This provides an excellent opportunity for organizations with almost no exposure to the risk of negatively affecting their existing markets.

Someone may argue that an increase in sales revenue from a new market can be achieved from exports too. This may be true, but there are two limitations of this approach in entering new markets through exports, particularly in low-income nations where consumers are highly pricesensitive: (i) exported products usually cost more as compared to indigenized products to consumers due to the high import duties on finished products and therefore, the sales revenue through exports will have a smaller impact on the annual income statement; (ii) secondly, the access to data on consumer behavior for new, pre-owned or refurbished products is expensive and valuable to organizations. The consumer data through export will be indirect and delayed due to a lack of direct marketing network. Both these reasons will result in the suboptimal performance of an organization in new markets.

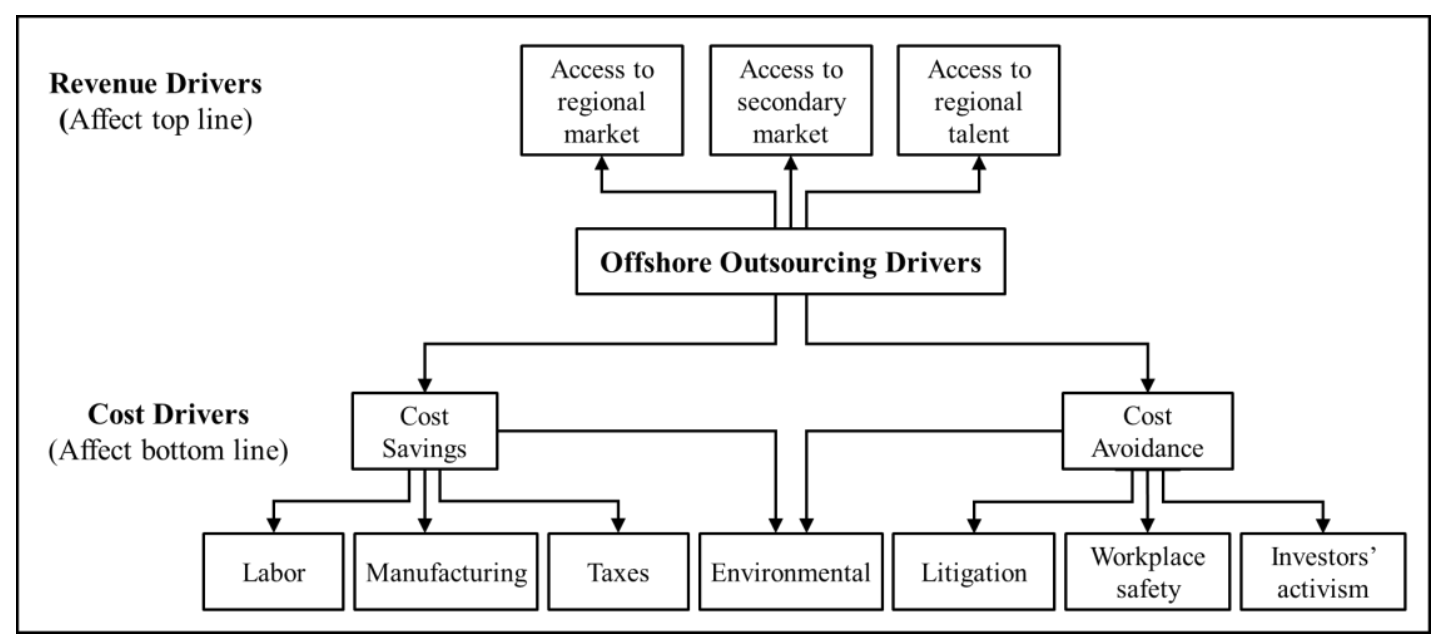

Figure $1 \mathrm{~A}$ framework for drivers of offshore outsourcing

\subsubsection{Access to Secondary Markets}

Many consumers in developing economies cannot afford to purchase new products or the latest models of various products due to their low purchasing power. Therefore, market access to non-mature markets also provides opportunities for offshoring organizations to sell 
pre-owned and refurbished products. Outsourcing organizations can either set up a refurbishing unit or outsource refurbishing activities at the same location and sell pre-owned products locally in these markets (Galbreth \& Blackburn, 2010). Refurbishing and reselling pre-owned products help make supply chains closed loop, reduces the lifecycle impacts of products on the environment, and makes them environmentally sustainable. This may also reduce waste, reduce recycling costs, and encourage sustainability initiatives amongst multinational organizations.

The markets for the new, as well as pre-owned and refurbished products, allow organizations to learn consumer behavior and their preferences in developing economies firsthand with relatively very little investment as compared to the cost of entering and experimenting in a mature or semi-mature market. The organizations, which enter early in the non-mature markets, gain a lot of insights from these nascent markets as well as increase sales revenue. Of note, the resulting additional sales revenue captured from offshore outsourcing decisions for new, preowned, and refurbished products are not reflected in any organizations' annual reports.

\subsubsection{Access to Talent Pool}

Some recent studies found that offshore outsourcing decisions help tap talent globally (Lewin et al., 2009) and to spur innovation (Valle et al., 2015). These studies argued that organizations are willing to pay competitively for talent in the global arena. The studies also found a positive association between the offshoring and the innovation output. Another study on the offshoring of R\&D as a strategy to the sales growth found that "offshore outsourcing positively affects sales growth both directly and indirectly" (Rodríguez \& Nieto, 2016). Therefore, it could be argued that labor cost arbitrage is not as important as projected in much of the academic literature. Organizations can be more competitive, creative, and innovative because of their exposure and access to global talent. Reasons associated with market expansion seem to project offshore outsourcing as a smart, responsible, and profitable decision.

\subsection{Cost Drivers}

This section discusses areas where organizations can save or avoid costs through an offshore outsourcing decision. The bottom half of Figure 1 represent cost drivers. The discussion is divided into sub-sections linked to cost drivers shown in Figure 1. However, as stated earlier, the savings linked to labor and manufacturing costs have been covered by many authors previously and therefore, we have not discussed it here.

\subsubsection{Tax Savings}

The tendency to avoid investments in environmentally friendly policies, technologies, and strategies is affected by the dichotomy in justifying the investment. On one side, there is a long period to justify the return on investments from these decisions. On the other side, there is a long period for measuring and quantifying the negative effects in the absence of investments in environmentally friendly policies, technologies, and strategies. An empirical study found that the mean time lag for measuring return on investments in the environmental costs was more than ten years (Regnier \& Tovey, 2007). Extended time frames for return on investment decisions tend to motivate business leaders to ignore investments in environmentally friendly technologies because they are under pressure to show improvements in the organizations' performance to their shareholders on a quarterly and annual basis. Another motivating factor in favor of offshore outsourcing is the tax advantages provided by the host country (Christensen, 2011; Pomerleau, 2014; Williamson, 2015). According to Tax Foundation, (i) "The United States has the third highest general top marginal corporate income tax rate in the world at 39.1 percent, exceeded only by Chad and the United Arab Emirates"; (ii) "The worldwide average top corporate income tax rate is 22.6 percent (30.6 percent weighted by GDP)"; and (iii) "By region, Europe has the lowest average corporate tax rate at 18.6 percent (26.3 percent weighted by GDP); Africa has the highest average tax rate at 29.1 percent."

\subsubsection{Environmental Cost}

Environmental costs of running manufacturing organizations in developed countries are significantly higher as compared to that of developing countries due to the stringent environmental laws, strict enforcement of the laws by various agencies, and close monitoring by NGOs in developed countries. There seems to be a consensus among academics that environmental laws are not nearly as stringent in the developing countries, as in the developed countries. Further, the enforcement of these less stringent laws is marginal, as governments in developing countries primarily focus on economic development, rather than equally focusing on social, environmental and economic developments. Outsourcing to developing countries often yields savings in the environmental cost of running an operation. However, these savings are accompanied by many negative impacts on the environment. A case study showed that oil exploration by a multinational organization led to environmental degradation in Nigeria (Eweje, 2006). The author also added, "It is becoming increasingly apparent to oil companies that pollution prevention pays while pollution does not and under pressure from stakeholder groups oil companies now routinely incorporate environmental impact assessments into their corporate strategy" (Eweje, 2006).

\subsubsection{Litigation Costs}

Business leaders are often reluctant to invest in the long-term environmental protection initiatives and want to accrue short-term savings by mitigating potential expenses of the litigation far ahead in the future. Offshore outsourcing kills two birds with one stone: offshoring provides many opportunities to save on long-term investments in technology to protect the environment and allows them to accrue short-term saving from mitigating potential expenses on litigation costs. The litigation costs fall under the category of cost avoidance in the long term. According to the U.S. Chamber Institute for Legal Reform, the litigation costs in the USA is the highest in the world (McKnight \& Hinton, 2013). A cost comparison among organizations by this agency in 2013 revealed that 
litigation costs as a fraction of GDP for the United States and China are 1.66 and 0.29 respectively, i.e., the cost of litigation in the United States is about six times that of China. Litigation costs are a huge incentive for business leaders to choose in favor of offshore outsourcing to developing countries.

\subsubsection{Workplace Safety Costs}

The cost of providing a safe workplace to workers is required of business leaders in developed countries. However, despite the best intentions of providing a safe workplace environment, accidents do happen. The costs of such accidents in the United States have a major impact on the bottom lines of the affected organizations. According to an estimate, the cost of workplace accidents is about $\$ 1$ billion per week towards direct workers' compensation (United States Department of Labor, 2016). "The United States had 96,000 fatal work-related diseases and 5,300 fatal occupational injuries, including an adjustment for under-reporting, while the competitiveness ranking was the highest in the world in 2008" (Takala et al., 2014). While this may seem like great news to workers and trade union leaders in developed countries, such as the USA, it provides motivation and encourages business leaders to decide in favor of offshoring to developing countries. Developing countries do not have stringent safety requirements established for protecting their workforce. Therefore, organizations in developing countries provide business leaders with more economical choices in the short term. Similar views were expressed by Greenblatt (2013) on the cost to benefit ratio in the United States, who estimated this ratio to be 16 to 1 . The above discussion is not intended to suggest that environmental regulations and workers' safety standards should be relaxed in developed countries. The purpose of the above discussion is to highlight an opportunity to enforce environmental laws and workers' safety norms in developing countries and to reduce an incentive to trade off environmental and workers' safety with short-term economic benefits.

\subsubsection{Investor' Activisms}

It is also important to note that shareholder and stakeholder activism related to corporate disclosures and policies on environment and labor issues have been on the rise in developed countries due to a strong legal system (Cormier \& Magnan, 1999). Environmentally and socially responsible strategies are value-enhancing for organizations in the long-term (McWilliams \& Siegel, 2000; Servaes \& Tamayo, 2013). However, the duration (long-term) provides motivation for business leaders to explore offshore outsourcing. Several organizations that focus on the short-term gains may try to avoid the consequences of shareholder and stakeholder activism by offshore contracting of their manufacturing activities in developing countries. The contractors and the subcontractors in the developing countries are engaged in greenwashing, by advertising that they follow environmentally friendly practices to cover their true activities because the environment and labor protection laws are weak in developing countries ( $\mathrm{Du}, 2015)$. Such activities may hurt the contractors and sub-contractors when exposed. In some ways, offshore outsourcing provides insulation from shareholder and stakeholder activism, protesting an organization's policies. Thus, some drivers associated with the cost savings or cost avoidance may have a dark side in outsourcing, wherein organizations use offshore outsourcing as a strategy to avoid regulations and legal costs in their home countries.

Our framework above provides a big picture of the real and less-discussed drivers of offshore outsourcing. The next section analyzes the composite effects of these drivers and discusses their impact on business.

\section{DISCUSSION}

The academic literature on non-cost-saving drivers that influence offshore outsourcing and their effects on decision-making processes is scanty. The framework presented in the preceding section presents a holistic view of offshore outsourcing. The framework also provided some insights into the less-discussed drivers of offshore outsourcing. One of these drivers alone, may not be persuasive enough to impact the final determination to outsource offshore. However, combining the economic advantages and benefits against the slightly higher cost of logistics often leads to a business decision in favor of offshore outsourcing. This framework also illustrates that labor cost savings play a small role and are not significant enough to sway the decision in favor of offshore outsourcing. These decisions are almost always influenced by the savings potential from the factors other than labor cost discussed above.

However, the inclusion of parameters to protect the environment and the societies affected by the offshoring is likely to yield a different outcome. The environment is a shared resource and its protection is a shared responsibility (Cassen, 1987). Therefore, we would like to reiterate that we are not suggesting removal or weakening of environmental laws or compromising workers' safety standards in developed countries to make them more competitive versus offshore outsourcing. The availability of clean potable water and clean, breathable air are fundamental needs of every individual across the globe. However, the challenge remains in ensuring clean air and water are available to all. How will a clean environment be possible to all people, when more and more corporate leaders are choosing to move the locations of their manufacturing or sourcing to the nations where environmental and labor laws or their enforcement is either weak or non-existent?

The technology transfer to manufacturing and energy generation in developing countries is dated and inefficient. Older technology in manufacturing and energy generation in developing countries helps keep the cost of manufacturing low, albeit at the expense of environmental sustainability. This provides a financial advantage to organizations that outsource the manufacturing operations to offshore destinations where the environmental costs of doing business, as compared to developed countries such as the USA or the EU, is very low. These arguments must not be construed to portray offshore outsourcing as evil. On the contrary, we believe that offshore outsourcing is a great tool for developing other nations so long as it does not impact the environment and societies negatively. However, organizations do not choose offshore outsourcing 
destinations to nations that have cleaner manufacturing than their existing manufacturing locations, because the costs of manufacturing in cleaner nations are generally higher. This begs an important question - is offshore outsourcing a trade-off for environmental costs? The short answer appears to be an overwhelming yes. For example, Belgium has experienced a reduction in greenhouse gas, acidifying and tropospheric precursor emissions by 17 percent, 6 percent, and 7 percent respectively between 1995 and 2007 due to offshore outsourcing (Michel, 2013). Another example, showed that the United Kingdom and Denmark reduced $\mathrm{CO}_{2}$ emissions by 15.6 and 1.8 million tons respectively, due to offshore outsourcing to China, while China added about 120 and 22 million tons of $\mathrm{CO}_{2}$ for the same exports to the respective countries (Herrmann $\&$ Hauschild, 2009). The emissions tradeoff due to offshore outsourcing of manufacturing activities among the United States, Germany, and China has been discussed (Gurtu, Searcy, \& Jaber, 2016a). The authors showed a significant erosion in net profitability due to a carbon tax on excess emissions on the net imports. Their analysis showed an erosion of 43 percent of net profit in Walmart's bottom line in 2006 due to a carbon tax on excess emissions on the net imports (imports minus exports) from China to the USA (Gurtu et al., 2016a).

The costs of workplace safety and health expenses in the United States are one of the highest as discussed above. Does it also provide an incentive for offshore outsourcing? This can be tested by observing the choices of the destinations for offshore outsourcing. Which destinations are more favorable for offshore outsourcing? Do organizations outsource to nations where workers' health and workplace safety standards are the same or higher than those of the outsourcing countries or do they choose developing countries which have proven track records of inferior and unsafe working environment? Again, this argument is not intended to discourage or undermine the good work done by various agencies in developed nations in providing their workers with a safe working environment. However, there is a cost of providing a safe working environment for workers, which do indeed affect the bottom lines of corporate organizations. When organizations engage in offshore outsourcing, it is no longer their responsibility to take care of the workforce at the offshore locations, thereby, significantly reducing their operating costs. Some may argue otherwise. Is it practical to expect from the offshoring organizations to take care of workers at the offshore outsourced locations? Will the workplace safety laws of developed countries be enforced at those offshore locations and how will they be enforced? There are many cases where the unsafe working conditions and the poor maintenance of plants at the offshore outsourced locations have caused news headlines. We have also seen the lackluster responses from CEOs and company spokespersons to such news headlines.

As an example, one of the world's worst industrial tragedy took place in 1984 in the city of Bhopal, India. A poisonous gas leak from a poorly maintained plant of Union Carbide killed a total of about 15,000 people, of which about 5,000 died in their sleep in one unfortunate night, claiming an additional 3,000 over the next three days, with the remaining 7,000 over the coming years
(Amaeshi et al., 2008; Bisarya \& Puri, 2005). This tragedy ultimately poisoned over half a million people and affected their health for the rest of their lives. The settlement compensation for such a huge number of casualties was an insignificantly small amount of $\$ 470$ million. They did not reach a settlement for five years after the accident in 1989 (Chouhan, 2005; Cullinan et al., 1997; Dhara \& Dhara, 2010; Eckerman, 2005; Trotter et al., 1989). However, many victims were fighting for the claim as late as in 2014 (Francis, 2014). In another recent example, Foxconn, a major manufacturer of electronic items for many big brands, such as Apple, Hewlett-Packard, Dell, Motorola, Nokia, and Sony among others, was accused of providing poor working conditions which led to a series of unfortunate suicides committed by its workers as a protest. Apple denied any knowledge of the poor working conditions and workers' problem at the outsourced locations. However, these suicides continued as a form of protest until 2012 (Frost \& Burnett, 2007; Lucas et al., 2013; Ngai \& Chan, 2012; Xu \& Li, 2013). In a more recent example, a fire in a garment plant in Bangladesh in 2013 killed more than 1,100 workers. These workers were earning their livelihood working in an unsafe environment for a Canadian organization which outsourced its garment manufacturing to Bangladesh. (Brown, 2015; Taplin, 2014; The Canadian Press, 2013). The combined cost of compensation for the lives of more than 1,100 workers was a few million dollars. There are over 3,000 such garments manufacturing factories in Bangladesh which manufacture garments for many well-known and reputed brands, such as Benetton, H\&M, C\&A, Tesco, Primark, and Zara among others, at a fraction of the cost.

Had such incidents taken place in the USA, the EU, or in Canada, the manufacturing organizations would have gone bankrupt due to the cost of compensation for so many lives. The CEOs or the spokespersons always express utter disbelief and absolute lack of the knowledge of such working conditions and are rarely held accountable. To be fair to offshoring organizations, it is impractical and an unfair expectation of CEOs or business leaders to know the working conditions of contractors and sub-contractors in global outsourced supply chains. Not providing for safe work environments translates into the much-advertised savings in the labor costs. Many important cost factors outweigh the labor costs and are conveniently ignored when making offshore outsourcing decisions, to avoid public scrutiny. Ignoring such factors also provides plausible deniability in case of any unfortunate events at the offshore outsourced locations.

The organizations showing environmentally and socially responsible policies receive a positive stock market response, whereas policies harming the environment and negatively affecting labor rights result in a negative stock market reaction (David et al., 2007; Flammer, 2013; Lydenberg, 2007). However, many companies focus only on short-term gains, attempting to wiggle out of their responsibilities and any consequences, by shipping their manufacturing activities far away from the eyes of their investors. These contractors and subcontractors may be able to engage in greenwashing if they operate in the developing countries with weak environmental and labor protection laws (Du, 2015; Lund- 
Thomsen et al., 2016). Offshore outsourcing can indeed provide insulation to corporations from shareholder and stakeholder activism related to corporate disclosures and adherence to environmental and labor laws.

Most of the consumers are unaware of the working conditions and treatment of workers at the offshore outsourced locations. The consumers are not impacted immediately by the severe environmental problems caused by offshore outsourcing to such destinations. Most consumers' buying decisions are based solely on price. Several existing studies and reports make the customers believe that offshore outsourcing leads to a reduction in labor and manufacturing costs, thereby making goods and services cheaper. There is a limited discussion about the detrimental effects of offshore outsourcing on the environment or the prevailing working conditions at these locations. In these cases, should the consumers be made aware of the environmental and social implications associated with offshore outsourcing, individual consumers buying patterns would very likely to be affected? The inclusion of environmental and social parameters formally into the decision-making framework will present challenges for practitioners who may choose to present different opportunities and choices to management.

\section{CONCLUSION}

This paper critically looked at the important drivers of offshore outsourcing. We categorized the drivers of offshore outsourcing, which reduce costs as well as improve revenues. Further, we presented a framework to facilitate the identification of drivers to make a holistic decision on the offshoring. The analysis illustrated a fallacy that offshore outsourcing is predominantly due to the savings in labor costs is untrue. The paper argued that the much talked about labor cost savings may be a misnomer or has a very small impact in most cases involving an offshore outsourcing decision. In fact, other drivers of costs and benefits discussed in this paper appear to be more prominent for an offshore outsourcing decision than the savings in the labor cost alone. The decision makers may not talk about all these lesser known factors for various reasons such as political correctness, plausible deniability, or avoiding attention from consumers and stakeholders.

Our paper is the first work to discuss the costs and the benefits of offshoring decisions in a holistic manner and provides a starting point for a thorough discussion on the needs for a comprehensive strategy for the offshore outsourcing. The discussion should lead to building a framework for developing a global policy on offshore outsourcing. The current approach to deciding on offshore outsourcing is very myopic and harming the environment and societies. We believe an international policy on offshoring, similar Sarbanes-Oxley Act, for environment and society, holding CEOs responsible for all of their operations irrespective of its location might help minimize the detrimental effects of reckless offshore outsourcing.

The limitation of this paper is that we have considered only the selected papers to support each theme of drivers. This paper could be extended in many ways. One possible extension is providing a legal framework for making offshore outsourcing decisions. Another possibility is to draft a global policy which can be enforced by the World Trade Organization (WTO). This paper could also be extended to include an estimation of the total compensation paid by the organizations due to various disasters or accidents at the offshore outsourced locations, as well as the cost avoided in communication and public relations over the last few decades. Another possible extension is testing this framework with empirical evidence.

\section{ACKNOWLEDGEMENTS}

Ramesh Saxena thanks Humber College, Toronto.

\section{REFERENCES}

Amaeshi, K. M., Osuji, O. K., \& Nnodim, P. (2008). Corporate social responsibility in supply chains of global brands: A boundaryless responsibility? Clarifications, exceptions and implications. Journal of Business Ethics, 81(1), pp. 223234.

Barry, C., \& Reddy, S. G. (2006). International Trade and Labor Standards : A Proposal for Linkage. Cornell International Law Journal, 39(3), pp. 545-639.

Bisarya, R. K., \& Puri, S. (2005). The Bhopal gas tragedy-A perspective. Journal of Loss Prevention in the Process Industries, 18(4-6), pp. 209-212.

Bock, S. (2008). Supporting offshoring and nearshoring decisions for mass customization manufacturing processes. European Journal of Operational Research, 184(2), pp. 490-508.

Brown, G. (2015). Bangladesh: currently the worst, but possibly the future's best. New Solutions: A Journal of Environmental and Occupational Health Policy: NS, 24(4), pp. 469-473.

Bunyaratavej, K., Hahn, E. D., \& Doh, J. P. (2007). International offshoring of services: A parity study. Journal of International Management, 13(1), pp. 7-21.

Bunyaratavej, K., Hahn, E. D., \& Doh, J. P. (2008). Multinational investment and host country development: Location efficiencies for services offshoring. Journal of World Business, 43(2), pp. 227-242.

Cachon, G. P., \& Harker, P. T. (2002). Competition and Outsourcing with Scale Economies. Management Science, 48(10), pp. 1314-1333.

Cassen, R. H. (1987). Our common future: report of the World Commission on Environment and Development. International Affairs, 64(1), pp. 126-126.

Chouhan, T. R. (2005). The unfolding of Bhopal disaster. Journal of Loss Prevention in the Process Industries, 18(4-6), pp. 205-208.

Christensen, J. (2011). The looting continues: tax havens and corruption. Critical Perspectives on International Business, 7(2), pp. 177-196.

Cormier, D., \& Magnan, M. (1999). Journal of Accounting, Auditing \& Finance. Journal of Accounting, Auditing \& Finance, 14(4), pp. 429-451.

Cullinan, P., Acquilla, S., \& Dhara, V. R. (1997). Respiratory morbidity 10 years after the Union Carbide gas leak at Bhopal: a cross sectional survey. BMJ, 314(7077), pp. 338 338.

David, P., Bloom, M., \& Hillman, A. J. (2007). Investor activism, managerial responsiveness, and corporate social performance. Strategic Management Journal, 28(1), pp. 91-100.

Davis, B. (2016). This Chinese Company Moved Production to South Carolina to Save Money. The Wall Street Journal. Feb. 17

Dey, A., LaGuardia, P., \& Srinivasan, M. (2011). Building sustainability in logistics operations: A research agenda. Management Research Review, 34(11), pp. 1237-1259. 
Dhara, V. R., \& Dhara, R. (2010). The Union Carbide disaster in Bhopal: a review of health effects. Archives of Environmental Health, 57(5), pp. 391-404.

$\mathrm{Du}, \mathrm{X}$. (2015). How the Market Values Greenwashing? Evidence from China. Journal of Business Ethics, 128(3), pp. 547574.

Eckerman, I. (2005). The Bhopal gas leak: Analyses of causes and consequences by three different models. Journal of Loss Prevention in the Process Industries, 18(4-6), pp. 213-217.

Ehie, I. C. (2001). Determinants of success in manufacturing outsourcing decisions: A survey study. Production and Inventory Management Journal, 42(1), pp. 31-39.

Eldenburg, L., Price, R. A., \& Rommn, F. J. (2014). The Role of Labor and Transaction Costs in the Success of Manufacturing Offshore: Evidence from Mexico's Maquiladora Industry. SSRN Electronic Journal, November, pp. 58.

Ellram, L. M., Tate, W. L., \& Billington, C. (2008). Offshore outsourcing of professional services: A transaction cost economics perspective. Journal of Operations Management, 26(2), pp. 148-163.

Eweje, G. (2006). Environmental Costs and Responsibilities Resulting from Oil Exploitation in Developing Countries: The Case of the Niger Delta of Nigeria. Journal of Business Ethics, 69(1), pp. 27-56.

Flammer, C. (2013). Corporate Social Responsibility and Shareholder Reaction: The Environmental Awareness of Investors. Academy of Management Journal, 56(3), pp. $758-781$.

Francis, A. (2014). Why are Bhopal survivors still fighting for compensation? Retrieved June 6, 2018, from https://www.bbc.com/news/world-asia-india-30205140

Frost, S., \& Burnett, M. (2007). Case study: the Apple iPod in China. Corporate Social Responsibility and Environmental Management, 14(2), pp. 103-113.

Galbreth, M. R., \& Blackburn, J. D. (2010). Offshore Remanufacturing with Variable Used Product Condition. Decision Sciences, 41(1), pp. 5-20.

Ghodeswar, B., \& Vaidyanathan, J. (2008). Business process outsourcing: an approach to gain access to world-class capabilities. Business Process Management Journal, 14(1), pp. 23-38

Gooris, J., \& Peeters, C. (2014). Home-host country distance in offshore governance choices. Journal of International Management, 20(1), pp. 73-86.

Greenblatt, D. (2013). What's the True Cost of Environmental Regulation? Retrieved January 9, 2016, from http://www.inc.com/drew-greenblatt/true-cost-ofenvionmental-regulation.html

Gurtu, A., Searcy, C., \& Jaber, M. Y. (2016a). A Framework for Reducing Global Manufacturing Emissions. Journal of Environment and Development, 25(2), pp. 159-190.

Gurtu, A., Searcy, C., \& Jaber, M. Y. (2016b). Effects of offshore outsourcing on a nation. Sustainable Production and Consumption, 7(April), pp. 94-105.

Hagerty, J. R., \& Magnier, M. (2015). Companies Tiptoe Back Toward 'Made in the U.S.A.' Retrieved April 30, 2016, from http://www.wsj.com/articles/companies-tiptoe-backtoward-made-in-the-u-s-a-1421206289

Herrmann, I. T., \& Hauschild, M. Z. (2009). Effects of globalisation on carbon footprints of products. CIRP Annals, 58(1), pp. 13-16.

Holcomb, T. R., \& Hitt, M. A. (2007). Toward a model of strategic outsourcing. Journal of Operations Management, 25(2), pp. 464-481.

Honeycutt, E. D., Magnini, V. P., \& Thelen, S. T. (2012). Solutions for customer complaints about offshoring and outsourcing services. Business Horizons, 55(1), pp. 33-42.
Javalgi, R. G., Dixit, A., \& Scherer, R. F. (2009). Outsourcing to emerging markets: Theoretical perspectives and policy implications. Journal of International Management, 15(2), pp. $156-168$.

Jensen, P. D. Ø., \& Pedersen, T. (2010). The Economic Geography of Offshoring: The Fit Between Activities And Local Context. Journal of Management Studies, 48(2), pp. 352-372.

Kedia, B. L., \& Lahiri, S. (2007). International outsourcing of services: A partnership model. Journal of International Management, 13(1), pp. 22-37.

Kedia, B. L., \& Mukherjee, D. (2009). Understanding offshoring: A research framework based on disintegration, location and externalization advantages. Journal of World Business, 44(3), pp. 250-261.

Keuschnigg, C., \& Ribi, E. (2009). Outsourcing, unemployment and welfare policy. Journal of International Economics, 78(1), pp. 168-176.

Kshetri, N. (2007). Institutional factors affecting offshore business process and information technology outsourcing. Journal of International Management, 13(1), pp. 38-56.

Kshetri, N., \& Dholakia, N. (2009). Professional and trade associations in a nascent and formative sector of a developing economy: A case study of the NASSCOM effect on the Indian offshoring industry. Journal of International Management, 15(2), pp. 225-239.

Lahiri, S. (2016). Does Outsourcing Really Improve Firm Performance? Empirical Evidence and Research Agenda. International Journal of Management Reviews, 18(4), pp. 464-497.

Larsen, M. M., Manning, S., \& Pedersen, T. (2013). Uncovering the hidden costs of offshoring: The interplay of complexity, organizational design, and experience. Strategic Management Journal, 34(5), pp. 533-552.

Lee, R. T. (2014). Making Better Offshoring and Onshoring Decisions. Journal of Corporate Accounting \& Finance, 25(6), pp. 35-38.

Lewin, A. Y., Massini, S., \& Peeters, C. (2009). Why are companies offshoring innovation? The emerging global race for talent. Journal of International Business Studies, 40(6), pp. 901-925.

Lucas, K., Kang, D., \& Li, Z. (2013). Workplace Dignity in a Total Institution: Examining the Experiences of Foxconn's Migrant Workforce. Journal of Business Ethics, 114(1), pp. 91-106.

Lund-Thomsen, P., Lindgreen, A., \& Vanhamme, J. (2016). Industrial Clusters and Corporate Social Responsibility in Developing Countries: What We Know, What We do not Know, and What We Need to Know. Journal of Business Ethics, 133(1), pp. 9-24.

Lydenberg, S. (2007). Universal Investors and Socially Responsible Investors: a tale of emerging affinities. Corporate Governance: An International Review, 15(3), pp. 467-477.

Marin, D. (2006). A New International Division of Labor in Europe: Outsourcing and Offshoring to Eastern Europe. Journal of the European Economic Association, 4(2-3), pp. 612-622.

Maskell, P., Pedersen, T., Petersen, B., \& Dick-Nielsen, J. (2007). Learning Paths to Offshore Outsourcing: From Cost Reduction to Knowledge Seeking. Industry \& Innovation, 14(3), pp. 239-257.

Mason, S. J., Cole, M. H., Ulrey, B. T., \& Yan, L. (2002). Improving electronics manufacturing supply chain agility through outsourcing. International Journal of Physical Distribution \& Logistics Management, 32(7), pp. 610-620.

McKnight, D. L., \& Hinton, P. J. (2013). International Comparisons of Litigation Costs. Retrieved January 19, 2018, 
http://www.instituteforlegalreform.com/research/internatio nal-comparisons-of-litigation-costs-europe-the-unitedstates-and-canada

McWilliams, A., \& Siegel, D. (2000). Corporate social responsibility and financial performance: correlation or misspecification? Strategic Management Journal, 21(5), pp. 603-609.

Michel, B. (2013). Does offshoring contribute to reducing domestic air emissions? Evidence from Belgian manufacturing. Ecological Economics, 95, pp. 73-82.

Mihalache, O. R., Jansen, J. J. J. P., Van Den Bosch, F. A. J., \& Volberda, H. W. (2012). Offshoring and firm innovation: The moderating role of top management team attributes. Strategic Management Journal, 33(13), pp. 1480-1498.

Mudambi, R., \& Venzin, M. (2010). The Strategic Nexus of Offshoring and Outsourcing Decisions. Journal of Management Studies, 47(8), pp. 1510-1533.

Murray, M. (2017). Reducing Supply Chain Transportation Costs. Retrieved January 24, 2018, from https://www.thebalance.com/reducing-transportationcosts-2221049

Musteen, M. (2016). Behavioral factors in offshoring decisions: A qualitative analysis. Journal of Business Research, 69(9), pp. 3439-3446.

Nassif, M., \& Roe, W. (2009). Who moved MY job? Competitiveness Review, 19(1), pp. 36-45.

Ngai, P., \& Chan, J. (2012). Global Capital, the State, and Chinese Workers: The Foxconn Experience. Modern China, 38(4), pp. 383-410.

OECD. (2016). Glossary of Statistics Terms. Retrieved June 17, 2016, from https://stats.oecd.org/glossary/alpha.asp?Let=O

Panova, Y., \& Hilletofth, P. (2017). Feasibility of Nearshoring European Manufacturing Located in China to Russia. Operations and Supply Chain Management: An International Journal, 10(3), pp. 141-148.

Parida, V., Wincent, J., \& Oghazi, P. (2016). Transaction costs theory and coordinated safeguards investment in R\&D offshoring. Journal of Business Research, 69(5), pp. 18231828.

Pashupatimath, G. R., \& Ramakrishna, H. (2015). Global engineering offshore outsourcing - a literature review. International Journal of Business and Systems Research, 9(1), pp. 32.

Pomerleau, K. (2014). Corporate Income Tax Rates around the World, 2014. Retrieved January 8, 2016, from http://taxfoundation.org/article/corporate-income-taxrates-around-world-2014

Regnier, E., \& Tovey, C. (2007). Time horizons of environmental versus non-environmental costs: evidence from US tort lawsuits. Business Strategy and the Environment, 16(4), pp. 249-265.

Reshoring Initiative. (2017). Retrieved October 8, 2017, from http://www.reshorenow.org/companies-reshoring/

Rodríguez, A., \& Nieto, M. J. (2016). Does R\&D offshoring lead to SME growth? Different governance modes and the mediating role of innovation. Strategic Management Journal, 37(8), pp. 1734-1753.

Rugman, A. M., \& Verbeke, A. (2004). A perspective on regional and global strategies of multinational enterprises. Journal of International Business Studies, 35(1), pp. 3-18.

Servaes, H., \& Tamayo, A. (2013). The Impact of Corporate Social Responsibility on Firm Value: The Role of Customer Awareness. Management Science, 59(5), pp. 1045-1061.
Sheldon, P., \& Li, Y. (2013). Localized poaching and skills shortages of manufacturing employees among MNEs in China. Journal of World Business, 48(2), pp. 186-195.

Stanko, M. A., \& Calantone, R. J. (2011). Controversy in innovation outsourcing research: review, synthesis and future directions. $R \& D$ Management, 41(1), pp. 8-20.

Stringfellow, A., Teagarden, M. B., \& Nie, W. (2008). Invisible costs in offshoring services work. Journal of Operations Management, 26(2), pp. 164-179.

Takala, J., Hämäläinen, P., Saarela, K. L., Yun, L. Y., Manickam, K., Jin, T. W., ... Lin, G. S. (2014). Global estimates of the burden of injury and illness at work in 2012. Journal of Occupational and Environmental Hygiene, 11(5), pp. 326337.

Taplin, I. M. (2014). Who is to blame? Critical Perspectives on International Business, 10(1/2), pp. 72-83.

Tate, W. L., Ellram, L. M., Schoenherr, T., \& Petersen, K. J. (2014). Global competitive conditions driving the manufacturing location decision. Business Horizons, 57(3), pp. 381-390.

The Canadian Press. (2013). Bangladesh Factory Collapse: Loblaws To Compensate Families. Retrieved May 22, 2016,

http://www.huffingtonpost.ca/2013/10/24/loblawsbangladesh-factory-collapse_n_4156569.html

Tjader, Y. C., Shang, J. S., \& Vargas, L. G. (2010). Offshore outsourcing decision making: A policy-maker's perspective. European Journal of Operational Research, 207(1), pp. 434-444.

Trotter, R. C., Day, S. G., \& Love, A. E. (1989). Bhopal, India and Union Carbide: The second tragedy. Journal of Business Ethics, 8(6), pp. 439-454.

United States Department of Labor. (2016). Safety and Health Topics, Business Case for Safety and Health, Occupational Safety and Health Administration. Retrieved October 7, 2016, from https://www.osha.gov/dcsp/products/topics/businesscase/

Valle, S., García, F., \& Avella, L. (2015). Offshoring Intermediate Manufacturing: Boost or Hindrance to Firm Innovation? Journal of International Management, 21(2), pp. 117-134.

Varadarajan, R. (2009). Outsourcing: Think more expansively. Journal of Business Research, 62(11), pp. 1165-1172.

White, W., \& Borchers, A. (2016). Motivation Behind Reshoring Decisions in Manufacturing. Operations and Supply Chain Management: An International Journal, 9(3), pp. 205-209.

Why Reshore? (2016). Retrieved February 24, 2016, from http://www.reshorenow.org/why-reshore/

Williamson, P. J. (2015). The competitive advantages of emerging market multinationals: a re-assessment. Critical Perspectives on International Business, 11(3/4), pp. 216235.

Xu, K., \& Li, W. (2013). An Ethical Stakeholder Approach to Crisis Communication: A Case Study of Foxconn's 2010 Employee Suicide Crisis. Journal of Business Ethics, 117(2), pp. 371-386.

Yamauchi, F. (2016). Rising real wages, mechanization and growing advantage of large farms: Evidence from Indonesia. Food Policy, 58, pp. 62-69.

Yang, D. T., Chen, V. W., \& Monarch, R. (2010). Rising Wages: Has China Lost Its Global Labor Advantage? Pacific Economic Review, 15(4), pp. 482-504.

Amulya Gurtu is an Associate Professor of Supply Chain Management in the Austin E. Cofrin School of Business at the University of Wisconsin-Green Bay, USA. His research is on sustainable supply chain management, logistics management, and offshore outsourcing. His research has been published in the International Journal of Nonprofit and Voluntary Sector Marketing, the Journal of Environment \& Development, Management Research Review, the Journal of Cleaner Production, Sustainable Production and Consumption, and Applied Mathematical Modelling. He is a manuscript reviewer of many reputed 
journals and currently the Editor-in-Chief of the International Journal of Sustainable Entrepreneurship and Corporate Social Responsibility.

Ramesh Saxena is Professor of Accounting and Finance at The Business School, Humber College, Toronto, Canada. He obtained his Ph.D. from JNU, New Delhi, India, M.A. in Economics from the University of Toronto, and M.B.A. from the University of Ottawa, Ottawa, Canada. His research has been published in the Journal of World Trade, World Competition and UNCTAD. He is a reviewer of the Journal of Advances in Economics and Business.

Nilesh Sah is an Assistant Professor of Finance in the Department of Finance \& Economics at Gary W. Rollins College of Business, University of Tennessee at Chattanooga. He completed his Ph.D. in Finance from the University of South Florida. His research is targeted towards Corporate Governance, Corporate and Behavioral Finance, Financial Markets and the application of concepts in Accounting and Finance in other fields like International Business and Supply Chain Management. He has presented his research at numerous national and international conferences. He has published his research in journals like Journal of Economics and Finance, Journal of Economics and Business, Quarterly Review of Economics and Finance and Managerial Finance. 